vision of disablement allowances and the guarantee of a certain rate of interest on policies issued by the association.

We see, therefore, that, through the administration of a great private benefaction, there has been evolved in America a pension system which in general form is not dissimilar from the Federated Superannuation System for Universities and University Colleges in this country. There are, however, important difterences. Whereas our federated system is in all essentials applied uniformly throughout the institutions concerned, the rew system in America is subject to a variety of conditions as to the rate of contribution, the grades of staff admitted, and other qualifications as to length of service and amount of salary. Also, while some institutions make entrance to the scheme compulsory on all members of certain grades of staff, others leave it entirely to the option of the individuals. So long as this lack of uniformity continues, the simplicity of transfer from one institution to another, so valuable a feature of the English system, can scarcely be secured. It is further to be observed that the rate of contribution of the American college is never more than 5 per cent., as compared with the Io per cent. now generally given by the English university; but against this must be put the fact that the policies issued by the American Teachers' Association are a little more generous in their terms than those of the insurance companies in our federated system.

A particularly useful section of the fourteenth report of the Foundation is that which deals with current pension problems both in America and in this country. It is here that we are most impressed with the almost chaotic condition of the pension arrangements in America as a result of the diversity of the State systems; but we are bound, on the other hand, to confess that our own Fisher scheme, while ad. mitted to be generous, comes in for severe criticism, especially on account of its non-contributory basis and of the alleged weakness of the arguments used to support the adoption of a scheme of that character. Indeed, throughout the report the virtues of the contributory plan are urged repeatedly and with great insistence, and we cannot dismiss lightly the opinions of an authority occupying the unique position of the Carnegie Foundation. Though perhaps not within the sphere of immediate practical politics, it is legitimate to conjecture whether greater advantage would not result from a contributory system of pensions applied to the whole of our teaching profession than -from a non-contributory system granted to a part of it. By the former plan we should recognise the essential unity of a great profession; by the latter we tend to separate it into parts and hamper the free interchange of teachers between one institution and another.

Those who are concerned in unravelling the knots in our own pension systems will find much suggestive material in this and previous reports of the Carnegic Foundation. But it is gratifying to feel that without the colossal munificence of a Carnegie we have yet reached a position which, with all its weaknesses, is still in many ways far in advance of that occupied by our Transatlantic cousins. Though we may regret lost opportunities, we realise that in a comparative sense we are not so badly off as we thought and we are led to ask ourselves whether, after all the scheme inspired by Sir William M'Cormick's Committee and designed by our universities in comoperation does not represent the best thing so far done in the matter of teachers' pensions.

In addition to its achievements in the pensions field, a valuable series of educational reports stands to the credit of the Carnegie Foundation. Under this head the papers contained in the fourteenth report on current tendencies in education, on legal education, and on the training of teachers are worthy of notice, though perhaps not so much for their discovery of new ideas as for their clear exposition of accepted principles and their straightforward description of the good and the bad in existing practice.

\section{National Food Consumption in the United States.}

PROF. RAYMOND PEARL has contributed to the Proceedings of the American Philosophical Society (vol. lviii., I9I9, p. I82) an instructive article upon the consumption of foodstuffs in America from I9 I I to I9I8. He distinguishes between (I) primary foods, such as plant materials directly consumable by man, or animals not nourished upon primary foodstuffs, and (2) secondary foods, which cover the edible products of animals nourished upon primary foodstuffs. The necessary deductions were made for loss in storage, transit, etc., and for inedible refuse. The statistics are expressed in terms of metric tons of proteins, carbohydrates, and fats, and also in terms of Calories.

Broadly speaking, the salient feature of the analysis is the uniformity of consumption from year to year. The greatest relative advance (relative, that is, to the increase of population) was in the consumption of fat, the least in the consumption of protein, but the deviations from the line of increasing population are small.

Turning to the sources, it appears that 47 per cent. of the protein is derived from primary, and 53 per cent. from secondary, foods. Of fats, 82 per cent. are derived from secondary sources, while 95 per cent. of the carbohydrates come from primary sources. In terms of Calories, 6r per cent. of the intake is from primary foodstuffs.

These figures are not greatly different from the British returns analysed by the Food (War) Committee of the Royal Society. We derived 42 per cent. of our protein, 92 per cent. of our fat, and 35 per cent. of our energy from secondary sources. Put otherwise, we get fewer Calories and less protein, but more fat, from animal sources (exclusive of fish, which comes under primary sources in Prof. Pearl's classification) than the Americans. We should, perhaps, use the past tense in this comparison, since the British datia do not refer to existing conditions.

Thirty-six per cent. of the American intake of protein is in the form of grain, 26 per cent. in meats, and 20 per cent. in dairy products. Of fat, $5^{\mathrm{I}}$ per cent. is furnished by meats, 27 per cent. by dairy products, and 12 per cent. by vegetable oils and nuts. Of carbohvdrates, 56 per cent. is furnished by grains and 26 per cent. by sugars. Of total energy, 35 per cent. comes from grains, 22 per cent. from meats, I5 per cent. from dairy products, and 13 per cent. from sugars. These four grouns contribute 85 per cent. of the total energy value.

The effects of the food economy campaign and the food administration in $1917-18$ are of interest. The total consumption of food increased, but not in proportion to the population; the consumption of meat practically did not increase at all, and the consumption of grain only $x$ per cent. The great increases were in the consumption of vegetables, of oils and nuts, and of oleomargarine, amounting respectively to 30 per cent., 20 per cent., and I 6 per cent over the averages of the preceding six years. The increase in the two former groups may have been due to the activity of 
the Food Administration in urging the consumption of these commodities to relieve the pressure upon wheat and animal products. The increased consumption of oleomargarine was no doubt due to a tavourable price in comparison with that of butter and lard.

Prof. Pearl provides a summary of daily consumption per "man," which again brings out the uniformity from year to year. The largest figure is 4361 Calories in $1913-14$, and the smallest 42 II in $1916-17$. The average figures are: 121 grams of protein, 169 grams of fat, and 542 grams of carbohydrate, yielding 4290 Calories. Assuming that 5 per cent. of protein, 20 per cent. of carbohydrate, and 25 per cent. of fat are lost in the wastage of edible substances, the per capita average of ingested food becomes:-Protein, II4 grams; fat, I27 grams; and carbohydrate, 433 grams, yielding 3424 Calories. These final figures are in good accord with the results of dietetic studies both in America and in England. Prof. Pearl justly remarks that "discussions of the minimum protein, fat, and carbohydrate requirements of a nation are in a considerable degree academic if they base themselves upon net consumption rather than gross consumption. A considerable excess over any agreed-upon minimum physiological requirements must always be allowed, because there will inevitably be, in fact, a margin between actual gross consumption and net physiological ingestion or utilisation."

The report is a useful contribution to knowledge. It is to be feared that since the armistice little attention has been devoted to the study of national dietetics in this country. During the war British physiologists made valuable experimental and statistical contributions to the subject; on the statistical side the work of the late Sir William Thompson, and on the experimental side that of Prof. Cathcart and his collaborators, deserve special mention. It is to be regretted that there is little prospect of the foundations then laid being built upon; it will be long indeed before the task of feeding the nation ceases to cause anxiety and to merit scientific elucidation.

M. G.

\section{Engineering Research in the U.S.A.}

THE problem of co-ordinating the interests and activities of the various engineering institutions and societies has been subject to much discussion in this country. In America this problem was largely solved by the establishment in 1904 of the United Engineering Society, which combined the interests of four founders' societies, namely, the American Society of Civil Engineers and the American Institutes of Mining and Metallurgical Engineers, Mechanical Engineers, and Electrical Engineers. The United Engineering Society now numbers some forty thousand members, and its administration comprises three principal departments, namely, the library board, the engineering council, and the engineering foundation. The last-named department is of particular interest, and is directed to the furtherance of research in science and engineering.

The engineering foundation was established as a result of a gift of 200,000 dollars by $\mathrm{Mr}$. Ambrose Swasey, this sum being used as the nucleus of a fund the income of which was to be devoted to research or for the advancement in any other manner of the profession of engineering and the good of mankind. This first gift was made in 1914 , and in September, I9I8, Mr. Swasey added a further sum of 100,000 dollars to the endowment.

The donor is an engineer and manufacturer, and president of the Warner-Swasey Co., of Cleveland, Ohio, a firm manufacturing fine tools and astro. NO. 2645 , VOL. IO5] nomical and other instruments of precision. $\mathrm{Mr}$. Swasey is a member of most of the American engineering societies, and of several English scientific societies, including the Royal Astronomical Society. $\mathrm{He}$ is the author of a number of papers read before American engineering societies.

For all practical purposes the engineering founda tion is a professional trust organised along the lines of the Carnegie, Rockefeller, and Sage foundations. The facilities it provides have heretofore been devoted principally to engineering research, and its most notable work has been conducted through co-operation with the National Research Council, which is an organisation of men of science, engineers, and educators brought into being by the National Academy of Science at the request of President Wilson in 1916 , and employed largely in the conduct of scientific investigations relating to anti-submarine and other war problems.

When the National Research Council was formed the administrators of the engineering foundation made themselves responsible for its financial support for a period of one year, and this brought into successful co-operation a body of engineering and scientific men in a comprehensive and practical manner.

Since July, I9 9 , the research work undertaken by the foundation has been of a very comprehensive nature. It has included, for example, preliminary researches on such subjects as a new hardness testing machine, the elimination of casting defects from steel, the uses of cadmium, the uses of alloy steels, Neumann bands in iron and steel, the heat treatment of carbon steel, electrical insulation, and substitute deoxidisers. A sum of I5,000 dollars a year for a period of two years has been voted for the conduct of research in the fatigue phenomena of metals in the laboratories of the engineering experiment station of the University of Illinois. From approximately fifty suggested subjects, the engineering foundation has also selected for investigation: (I) The wear of gears, (2) spray camouflage for ships, (3) the directive control of wireless communication, (4) weirs for the measurement of water, (5) the establishment of a testing station for large water-wheels and other large hydraulic equipment, and (6) the mental hygiene of industry.

These investigations are now all in progress or have been completed. Particular attention has been given to research relating to mental hygiene in industry, the objects of the research being to develop or discover methods for adapting psychopathetic individuals to usefulness in industry.

Realising, further, that mental hygiene dealt with only one of the many elements of the industrial personnel problem, the foundation board, in association with the National Research Council, arranged for the appointment of a committee representative of anthropology, psychology, educational relations, industrial relations, engineering, and medicine to consider means for furthering the study of the problems of industrial employment.

Quite apart from such efforts, the engineering foundation has interested itself in an attempt to coordinate the activities of many of the very numerous societies and associations, some local, some national, having a bearing on engineering, and to harmonise their relations and aims. Up to the present, however, no active investigational work along these lines has been undertaken. While the foundation maintains the closest relationship with the divisions of engineering of the United Engineering Society and the National Research Council, it reserves the right to conduct under its own immediate direction such researches as may commend themselves to its membershio. 